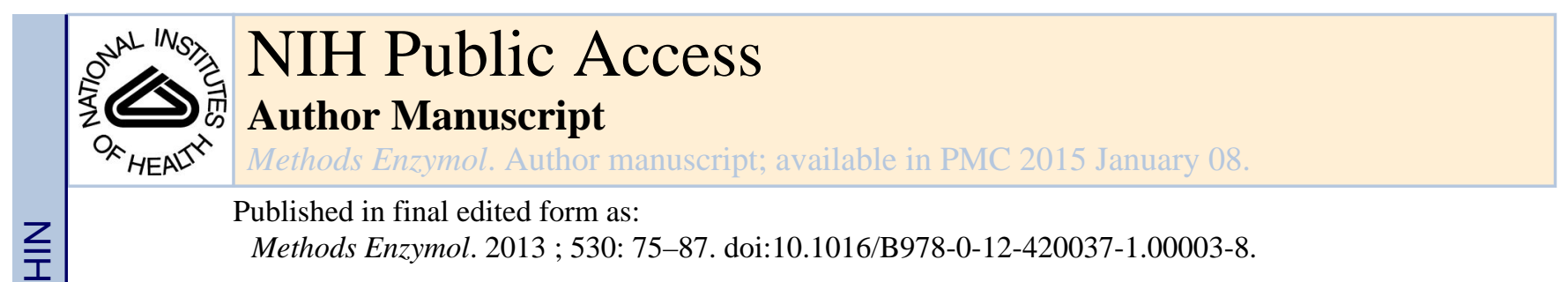

\title{
Northern blot
}

Shan L. He

Departement of Molecular Biology and Genetics, The Johns Hopkins University School of Medicine, Baltimore, Maryland, USA

\section{Purpose}

To measure the size and amount of RNA transcribe from a specific gene of interest.

\section{Theory}

Northern blot first uses denaturing gel to separate RNA according to the size. The RNA is then transferred to a nylon membrane while keeping the same distribution in the gel. After fixing the RNA to the membrane, labeled probe complementary to the gene of interest is then added to hybridize to the immobilized RNA. The nonspecifically bound probes are then washed away. The solid membrane with probe specifically bound to RNA of interest is then dried, exposed and analyzed. Since northern blot uses size-dependent separation, this technique can not only determine the abundance but also the sizes of transcript of interest. It can be a very effective way to detect transcript variants of genes. However, if the amount of total RNA for the experiment is limited and expression level of transcript of interest is low, other techniques more sensitive than northern blot, such as quantitative RT-PCR, can be used.

\section{Equipment}

Agarose gel rig

Power supply

Microwave

Centrifuge

PCR machine

Heating block

Vacuum gel transfer system

Nylon membrane

UV crosslinker

Hybridization oven 
Hybridization bottles

G-50 sephadex spincolumn

Scintillation vial

Scintillation counter

Forceps

Pipetor tips

$1.5 \mathrm{ml}$ polypropylene tubes

Phosphor screen

Phosphor screen scanning equipment

ImageQuant software (Molecular Dynamics)

\section{Materials}

'Editor's note': The Materials section comprises two parts. The first part is a comprehensive list of chemicals and reagents needed for the experiment.

Example:

Agarose

MOPS

Sodium acetate

Ethylenediaminetetraacetic acid disodium salt dihydrate

$\mathrm{NaOH}$

$\mathrm{HCl}$

Formaldehyde

Glycerol

Ethidium bromide

Bromophenol blue

Xylene cyanol

Orange G

Formamide

Millennium RNA ladder (Ambion)

$\mathrm{MgCl}_{2}$

NTPs: ATP, CTP, GTP, UTP

$\left[a-P^{32}\right]-U T P$ 
Salmon sperm DNA

$\mathrm{NaCl}$

Sodium Citrate

Ficoll 400

Polyvinylpyrrolidone

Bovine Serum Albumin

SDS

Sodium heparin

$\mathrm{NaH}_{2} \mathrm{PO}_{4}$

$\mathrm{Na}_{2} \mathrm{HPO}_{4}$

Tris- $\mathrm{HCl}(\mathrm{pH} 8.0)$

DTT

Triton X-100

Spermidine, $\mathrm{pH} 7.0$

Taq buffer

Enzymes: T7 polymerase, Taq polymerase

\section{Solutions \& buffers}

\section{Step 1}

$10 \times$ MOPS buffer (Store at RT, protected from light)

\begin{tabular}{llll} 
Component & Final concentration & Stock & Amount/liter \\
\hline MOPS & $0.2 \mathrm{M}$ & - & $41.852 \mathrm{~g}$ \\
\hline Sodium acetate $\cdot 3 \mathrm{H}_{2} \mathrm{O}$ & $80 \mathrm{mM}$ & - & $10.89 \mathrm{~g}$ \\
EDTA & $10 \mathrm{mM}$ & - & $0.372 \mathrm{~g}$ \\
\hline
\end{tabular}

Adjust $\mathrm{pH}$ to 7.0 with $\mathrm{NaOH}$. Add water to 1 liter

Denaturing RNA gel

\begin{tabular}{llll} 
Component & Final concentration & Stock & Amount/150 ml \\
\hline MOPS buffer & $1 \times$ & $10 \times$ & $15 \mathrm{ml}$ \\
\hline Agarose & $1.2 \%(\mathrm{w} / \mathrm{v})$ & - & $1.8 \mathrm{~g}$ \\
\hline $\mathrm{H}_{2} \mathrm{O}$ & & & $132 \mathrm{ml}$ \\
\hline
\end{tabular}

Microwave 3 4 min to dissolve agarose; cool to be able to hold; add formaldehyde $2.8 \mathrm{ml}$. 
Running buffer

\begin{tabular}{llll} 
Component & Final concentration & Stock & Amount/liter \\
\hline MOPS buffer & $1 \times$ & $10 \times$ & $100 \mathrm{ml}$ \\
\hline formaldehyde & $7 \%$ & $37 \%$ & 19 \\
\hline
\end{tabular}

Add water to 1 liter

$2 \times$ RNA loading buffer

\begin{tabular}{llll} 
Component & Final concentration & Stock & Amount/10ml \\
\hline MOPS buffer & $1 \times$ & $10 \times$ & $1 \mathrm{ml}$ \\
\hline glycerol & $20 \%$ & $100 \%$ & $2 \mathrm{ml}$ \\
\hline formaldehyde & $6.5 \%$ & $37 \%$ & $1.76 \mathrm{ml}$ \\
\hline Formamide & $50 \%$ & $100 \%$ & $5 \mathrm{ml}$ \\
\hline Ethidium Bromide & $10 \mu \mathrm{g} / \mathrm{ml}$ & - & $100 \mu \mathrm{g}$ \\
\hline Bromophenol blue & $0.05 \%(\mathrm{w} / \mathrm{v})$ & - & $5 \mathrm{mg}$ \\
\hline Xylene cyanol & $0.05 \%(\mathrm{w} / \mathrm{v})$ & - & $5 \mathrm{mg}$ \\
\hline
\end{tabular}

Add water to $10 \mathrm{ml}$

\section{Step 2}

$20 \times$ SSC buffer

\begin{tabular}{llll} 
Component & Final concentration & Stock & Amount/liter \\
\hline $\mathrm{NaCl}$ & $3 \mathrm{M}$ & - & $175.3 \mathrm{~g}$ \\
\hline Sodium Citrate & $300 \mathrm{mM}$ & - & $88.2 \mathrm{~g}$ \\
\hline
\end{tabular}

Adjust $\mathrm{pH}$ to 7.0 with $\mathrm{HCl}$, Add water to $1 \mathrm{~L}$.

10× SSC buffer

$500 \mathrm{ml} 20 \times \mathrm{SSC}$ buffer, add $\mathrm{H}_{2} \mathrm{O}$ to $1 \mathrm{~L}$.

\section{Step 3}

10× Transcription buffer

\begin{tabular}{llll} 
Component & Final concentration & Stock & Amount/10ml \\
\hline Tris-HCl, pH8.0 & $400 \mathrm{mM}$ & $1 \mathrm{M}$ & $4 \mathrm{ml}$ \\
\hline DTT & $50 \mathrm{mM}$ & $1 \mathrm{M}$ & $0.5 \mathrm{ml}$ \\
\hline Triton X-100 & $1 \%(\mathrm{v} / \mathrm{v})$ & $10 \%$ & $1 \mathrm{ml}$ \\
\hline
\end{tabular}




\begin{tabular}{llll} 
Component & Final concentration & Stock & Amount/10ml \\
\hline Spermidine, $\mathrm{pH} 7.0$ & $20 \mathrm{mM}$ & $500 \mathrm{mM}$ & $0.4 \mathrm{ml}$ \\
\hline $\mathrm{MgCl}_{2}$ & $200 \mathrm{mM}$ & $1 \mathrm{M}$ & $2 \mathrm{ml}$ \\
\hline
\end{tabular}

Add water to $10 \mathrm{ml}$

Sodium phosphate buffer, pH 8.0 (100 mM)

\begin{tabular}{lll} 
Component & Stock & Amount/liter \\
\hline $\mathrm{NaH}_{2} \mathrm{PO}_{4}$ & $0.2 \mathrm{M}$ & $473.5 \mathrm{ml}$ \\
\hline $\mathrm{Na}_{2} \mathrm{HPO}_{4}$ & $0.2 \mathrm{M}$ & $26.5 \mathrm{ml}$ \\
\hline
\end{tabular}

Add water to 1 liter

Denhardt's Solution 100x

\begin{tabular}{llll} 
Component & Final concentration & Stock & Amount/500ml \\
\hline Ficoll 400 & $0.02 \mathrm{~g} / \mathrm{ml}$ & - & $10 \mathrm{~g}$ \\
\hline Polyvinylpyrrolidone & $0.02 \mathrm{~g} / \mathrm{ml}$ & - & $10 \mathrm{~g}$ \\
\hline Bovine serum albumin & $0.02 \mathrm{~g} / \mathrm{ml}$ & - & $10 \mathrm{~g}$ \\
\hline
\end{tabular}

Add water to $500 \mathrm{ml}$

Hybridization buffer

\begin{tabular}{llll} 
Component & Final concentration & Stock & Amount/250ml \\
\hline Formamide & $50 \%$ & $100 \%$ & $125 \mathrm{ml}$ \\
\hline SSC & $3 \times$ & $20 \times$ & $37.5 \mathrm{ml}$ \\
\hline Denhardt's Solution & $10 \times$ & $100 \times$ & $25 \mathrm{ml}$ \\
\hline Sodium phosphate buffer, $\mathrm{pH} 8.0$ & $10 \mathrm{mM}$ & $100 \mathrm{mM}$ & $25 \mathrm{ml}$ \\
\hline EDTA & $2 \mathrm{mM}$ & $500 \mathrm{mM}$ & $1 \mathrm{ml}$ \\
\hline SDS & $0.1 \%$ & $10 \%$ & $2.5 \mathrm{ml}$ \\
\hline Salmon sperm DNA & $200 \mu \mathrm{g} / \mathrm{ml}$ & $5 \mathrm{mg} / \mathrm{ml}$ & $10 \mathrm{ml}$ \\
\hline Sodium heparin & $400 \mathrm{U} / \mathrm{ml}$ & $5,000 \mathrm{U} / \mathrm{ml}$ & $20 \mathrm{ml}$ \\
\hline
\end{tabular}

Add water to $500 \mathrm{ml}$.

Low stringency wash buffer

\begin{tabular}{llll} 
Component & Final concentration & Stock & Amount/liter \\
\hline SSC & $2 \times$ & $20 \times$ & $100 \mathrm{ml}$ \\
\hline SDS & $0.1 \%$ & $10 \%$ & $10 \mathrm{ml}$ \\
\hline
\end{tabular}

Add water to $1 \mathrm{~L}$. 
High stringency wash buffer

\begin{tabular}{llll} 
Component & Final concentration & Stock & Amount/liter \\
\hline SSC & $0.1 \times$ & $20 \times$ & $50 \mathrm{ml}$ \\
\hline SDS & $0.1 \%$ & $10 \%$ & $10 \mathrm{ml}$ \\
\hline
\end{tabular}

Add water to $1 \mathrm{~L}$.

\section{Protocol}

Duration

\begin{tabular}{ll}
\hline Preparation & about 1 day \\
\hline Protocol & about 2 days \\
\hline
\end{tabular}

\section{Preparation}

Make all the buffers and autoclave or filter sterilize them.

Generate template by PCR for making probes complementary to sequence of interest. If RNA probe is needed, template used should have a $\mathrm{T} 7$ promoter sequence

(TAATACGACTCACTATAGGG)

\section{Caution}

RNase-free conditions are important to maintaining the integrity of RNA. Disposable gloves should be worn at all times and changed frequently. All reagents should be autoclaved or filter-sterilized. Consult your institute Radiation Safety Officer for proper ordering, handling, and disposal of radioactive materials.

\section{Step 1 Separate RNA by a denaturing gel}

\begin{tabular}{|c|c|}
\hline Overview & Use denaturing agarose gel with formaldehyde to separate RNA based on the size. \\
\hline Duration & $5 \mathrm{hrs}$ \\
\hline 1.1 & Assemble agarose gel rigs and make denaturing RNA gel solution. \\
\hline 1.2 & Pour the RNA gel in hood \\
\hline 1.3 & After gel solidify, equilibrate gel with running buffer for at least $30 \mathrm{~min}$ before running. \\
\hline 1.4 & $\begin{array}{l}\text { Mix } 15 \mu \mathrm{g} \text { RNA sample with equal volume of } 2 \times \text { RNA loading buffer. Dilute } 3 \mu \mathrm{g} \text { Millennium RNA } \\
\text { Markers in same volume of } 2 \times \text { RNA loading buffer. Incubate @ } 65^{\circ} \mathrm{C} \text { in the heating blocking for } 12 \sim 15 \\
\text { min and put samples on ice immediately afterwards. }\end{array}$ \\
\hline 1.5 & Load all the samples to equilibrated gel and leave space between first sample and RNA marker. \\
\hline 1.6 & Run gel at $125 \mathrm{~V}$ for about $3 \mathrm{hrs}$ \\
\hline Tip & $\begin{array}{l}\text { All the sample volume should not exceed the well volume of the gel comb. If RNA sample is too diluted, salt } \\
\text { precipitate the RNA and resuspend with less } \mathrm{H} 2 \mathrm{O} \text {. }\end{array}$ \\
\hline
\end{tabular}




\section{Step 2 Transfer RNA from gel to nylon membrane}

\begin{tabular}{ll}
\hline Overview & RNA is transferred from gel to nylon membrane using vacuum gel transfer system. \\
Duration & $2 \mathrm{hrs}$ \\
2.1 & $\begin{array}{l}\text { Cut a nylon membrane about (or bigger than) the size of the denaturing RNA gel. Cut a filter paper with } \\
\text { the same size as the nylon membrane. }\end{array}$ \\
2.2 & Rinse the RNA gel with $\mathrm{H}_{2} \mathrm{O}$. \\
2.3 & Fill the wells of the RNA gel with melted agarose. \\
2.4 & Wet the nylon membrane and filter paper first in $\mathrm{H}_{2} \mathrm{O}$ and then $10 \times \mathrm{SSC}$ buffer \\
2.5 & $\begin{array}{l}\text { Put wet filter paper on the vacuum porous stage and make sure the filter paper is in the area where the cut } \\
\text { window of the green plastic gasket is going to be. Place the wetted nylon membrane on top of the filter }\end{array}$ \\
paper. Make sure there is no air bubble between membrane and filter.
\end{tabular}

\section{Step 3 Hybridization}

\footnotetext{
Overview use in vitro $\mathrm{T} 7$ transcription to make radioactively labeled RNA probes complementary to RNA transcript of interest. The probes are then hybridized to the membrane. Nonspecifically bound probes are washed away after hybridization.

Duration $18 \mathrm{hrs}$

3.1 Put cross-linked nylon membrane in the hybridization bottle with the RNA-side up.

3.2 Add $10 \mathrm{ml}$ hybridization buffer (for small hybridization bottle) to the membrane. Incubate at $68^{\circ} \mathrm{C}$ for $1 \mathrm{hr}$ to pre-hybridize.

3.3 During pre-hybridization, start the probe transcription reaction. For a $20 \mu \mathrm{l}$ gene probe transcription reaction, combine 10-50 pmoles DNA template, $2 \mu \mathrm{l} 10 \times$ transcription buffer, $1 \mu \mathrm{l} 10 \mathrm{mM}$ ATP, $1 \mu \mathrm{l} 10$ $\mathrm{mM}$ GTP, $1 \mu \mathrm{l} 10 \mathrm{mM}$ CTP, $5 \mu \mathrm{l} 12.5 \mathrm{mM}$ [a-P ${ }^{32}$ ]-UTP and T7 polymerase (20 U/ $\mu \mathrm{l}$ final) in a PCR tube.

3.4 For a $20 \mu \mathrm{l}$ transcription reaction for Millennium Marker probe, combine $1 \mu \mathrm{g}$ DNA template, $2 \mu \mathrm{l} 10 \mathrm{x}$ transcription buffer, $1 \mu \mathrm{l}$ 10mM ATP, $1 \mu \mathrm{l} 10 \mathrm{mM}$ GTP, $1 \mu \mathrm{l} 10 \mathrm{mM}$ CTP, $1 \mu \mathrm{l} 10 \mathrm{mM}$ UTP, $2 \mu \mathrm{l} 12.5 \mathrm{mM}$

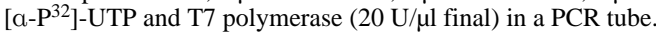

3.5 Incubate at $37^{\circ} \mathrm{C}$ for 2 hours.

3.6 Add $1 \mu \mathrm{l}$ DNase I and incubate at $37^{\circ} \mathrm{C}$ for $15 \mathrm{~min}$ to digest the template.

3.7 Snap off the bottom of micro G-50 sephadex spin column; open the cap by $1 / 4$ circle and put the column in a $1.75 \mathrm{ml}$ tube. Spin at $700 \mathrm{~g}$ for $1 \mathrm{~min}$. Put the column in a new $1.75 \mathrm{ml}$ tube.

3.8 Load transcription reaction carefully on top of the G-50 column. Spin at $700 \mathrm{~g}$ for $2 \mathrm{~min}$.
}

Methods Enzymol. Author manuscript; available in PMC 2015 January 08. 
3.9 Add $1 \mu \mathrm{l}$ of G-50 column purified probe to $5 \mathrm{ml}$ scintillation liquid and check the counts of the probes.

$3.10 \quad$ For gene probe, add $10^{6} \mathrm{cpm} / \mathrm{ml}$ to fresh hybridization buffer; for marker probe, add $0.2 \times 10^{6} \mathrm{cpm} / \mathrm{ml}$.

3.11 Dump the pre-hybridization solution and add hybridization buffer with probes to the hybridization bottle. Hybridize overnight at $68^{\circ} \mathrm{C}$ over night.

3.12 Pre-warm both the low stringency and high stringency buffer at $68{ }^{\circ} \mathrm{C}$.

$3.13 \quad$ Wash with low stringency for 5 min twice.

$3.14 \quad$ Wash with high stringency for 15 min twice.

3.15 Take out the membrane and brief dry it on kimwipe. Wrap the membrane with saran wrap and expose to a phosphor screen overnight.

Tip If the gene probe is longer than $400 \mathrm{nt}$, increase the limiting nucleotide (UTP in this case) concentration to $5-25 \mu M$ by adding more non-labeled UTP in the transcription reaction.

\section{References}

1. Dorner S, Lum L, Kim M, Paro R, Beachy PA, Green R. A genomewide screen for components of the RNAi pathway in Drosophila cultured cells. Proc Natl Acad Sci U S A. 2006; 103:11880118855. [PubMed: 16882716]

\section{TOPICS}

'Editor's note': Provide as many keywords as possible to this protocol using the table below as a guideline. Order the keywords based on importance. Not all protocols will necessarily have a keyword in each topic class.

\begin{tabular}{|c|c|}
\hline Topic Class & Keyword \\
\hline \multirow{5}{*}{$\begin{array}{l}\text { Methods } \\
\text { List the methods used to carry out this protocol (i.e., for each step). }\end{array}$} & 1 Denaturing agarose gel \\
\hline & 2 in vitro transcription \\
\hline & 3 \\
\hline & 4 \\
\hline & 5 \\
\hline \multirow{5}{*}{$\begin{array}{l}\text { Process } \\
\text { List the biological process(es) addressed in this protocol. }\end{array}$} & 1 RNA-RNA interaction \\
\hline & 2 \\
\hline & 3 \\
\hline & 4 \\
\hline & 5 \\
\hline \multirow{5}{*}{$\begin{array}{l}\text { Organisms } \\
\text { List the primary organism used in this protocol. List any other applicable organisms. }\end{array}$} & 1 \\
\hline & 2 \\
\hline & 3 \\
\hline & 4 \\
\hline & 5 \\
\hline \multirow{3}{*}{$\begin{array}{l}\text { Pathways } \\
\text { List any signaling, regulatory, or metabolic pathways addressed in this protocol. }\end{array}$} & 1 \\
\hline & 2 \\
\hline & 3 \\
\hline
\end{tabular}

Methods Enzymol. Author manuscript; available in PMC 2015 January 08. 


\begin{tabular}{|c|c|}
\hline Topic Class & Keyword \\
\hline & 4 \\
\hline & 5 \\
\hline \multirow{5}{*}{$\begin{array}{l}\text { Molecule role/function } \\
\text { List any cellular or molecular functions or activities addressed in this protocol. }\end{array}$} & 1 \\
\hline & 2 \\
\hline & 3 \\
\hline & 4 \\
\hline & 5 \\
\hline \multirow{5}{*}{$\begin{array}{l}\text { Phenotype } \\
\text { List any developmental or functional phenotypes addressed in this protocol (organismal or } \\
\text { cellular level). }\end{array}$} & 1 \\
\hline & 2 \\
\hline & 3 \\
\hline & 4 \\
\hline & 5 \\
\hline \multirow{5}{*}{$\begin{array}{l}\text { Anatomy } \\
\text { List any gross anatomical structures, cellular structures, organelles, or macromolecular } \\
\text { complexes pertinent to this protocol. }\end{array}$} & 1 \\
\hline & 2 \\
\hline & 3 \\
\hline & 4 \\
\hline & 5 \\
\hline \multirow{5}{*}{$\begin{array}{l}\text { Diseases } \\
\text { List any diseases or disease processes addressed in this protocol. }\end{array}$} & 1 \\
\hline & 2 \\
\hline & 3 \\
\hline & 4 \\
\hline & 5 \\
\hline \multirow{5}{*}{$\begin{array}{l}\text { Other } \\
\text { List any other miscellaneous keywords that describe this protocol. }\end{array}$} & 1 \\
\hline & 2 \\
\hline & 3 \\
\hline & 4 \\
\hline & 5 \\
\hline
\end{tabular}

\section{VIDEO}

'Editor's note': Indicate whether any protocol steps or sub-steps would be better illustrated by video (please also provide step or sub-step number e.g. Step 2 or sub-step 2.5).

\section{IMAGES}

It is ok to supply a copy of the figures as a reference within the manuscript in MS Word along with the list of legends. BUT LOW-RES IMAGES INSIDE A WORD DOC ARE NOT REPRO-QUALITY. All text and image files must be submitted via the website, http:// emss.elsevier.com. Use the website to post individual files of good-quality images. Login credentials to the website and author guidelines will be provided by Elsevier. 